\title{
Interleukin 8 in the cervix of non-pregnant ewes
}

\author{
S. E. Mitchell ${ }^{1}$, J. J. Robinson ${ }^{2}$, M. E. King², \\ W. A. C. McKelvey ${ }^{3}$ and L. M. Williams ${ }^{1 *}$ \\ ${ }^{1}$ Molecular Neuroendocrinology Group, The Rowett Research Institute, Greenburn Road, \\ Bucksburn, Aberdeen AB21 9SB, UK; ${ }^{2}$ Scottish Agricultural College, Craibstone Estate, \\ Aberdeen AB21 9YA, UK; and ${ }^{3}$ Scottish Agricultural College, West Mains Road, \\ Edinburgh EH9 3JG, UK
}

\begin{abstract}
Studies of cervical artificial insemination of ewes at hormone-synchronized oestrus indicate that the cervix remains relatively impenetrable to semen, in contrast to naturally breeding animals. During parturition the inflammatory response plays an important part in cervical dilation and possibly, to a lesser extent, in the non-pregnant cervix at oestrus to facilitate the transcervical transport of semen. The expression of interleukin 8 (IL-8), a pro-inflammatory cytokine in the ovine cervix, has been mapped and quantified, using semi-quantitative in situ hybridization, to ascertain the role played by inflammation in the ovine cervix during natural and artificially induced oestrous cycles. IL-8 gene expression was observed in both the luminal epithelium and fibroblastic cells of the cervix. The
\end{abstract}

presence of IL-8 was confirmed using immunohistochemistry. IL-8 gene expression in the luminal epithelium varied throughout the oestrous cycle and was highest at oestrus and at day 5 of the oestrous cycle. In ewes artificially induced to ovulate, either by the withdrawal of progesterone pessaries after treatment for 12 days, or by two i.m. injections of prostaglandin 9 days apart, IL-8 gene expression at oestrus was significantly lower than it was at natural oestrus. Insemination increased IL-8 gene expression in progesterone-synchronized ewes. These data support the hypothesis that IL-8-induced inflammation is important in normal cervical function and that this process is inhibited during artificial synchronization of the oestrous cycle and is increased by exposure to semen.

\section{Introduction}

The cervix acts as a barrier against ascending infection to the uterus and is important in the maintenance of pregnancy, before allowing the passage of the fetus at parturition (Dobson, 1988). However, in non-pregnant animals, a degree of patency of the cervix is important to allow the passage of semen so that fertilization can take place. In sheep, fixed-time artificial cervical insemination at a hormone-synchronized oestrus results in reduced sperm transport into the cervix (Hawk and Cooper, 1977) and decreased fertility. These findings are in contrast to intrauterine insemination, which bypasses the cervix and results in high pregnancy rates (McKelvey et al., 1985), and indicate that during artificial insemination the ovine cervix does not allow the free passage of semen. However, concern over the use of such an invasive procedure as laparoscopy, necessary for intrauterine insemination, makes it important to develop an efficient method of transcervical artificial insemination (Banner, 1995).

At parturition the cervix dilates as a result of tissue remodelling that is mainly the result of the degradation of its main component, collagen, via the inflammatory process. A number of markers of inflammation, including nitric

*Correspondence

Email: L.Williams@rri.sari.ac.uk oxide (Ekerhovd et al., 2000; Ledingham et al., 2000), prostaglandins (Gross et al., 1998; Reese et al., 2000; Wu et al., 2000) and the chemokine interleukin 8 (IL-8; Barclay et al., 1993; Kelly, 1996), are present in the cervix and are part of the inflammatory cascade at parturition that leads to the eventual recruitment of neutrophils, enzyme release and tissue breakdown. Inflammatory responses occur in the normal functioning of a number of reproductive organs, including the ovary and the uterus, as well as the cervix (Kelly et al., 1994; Arici et al., 1996; Garcia-Velasco and Arici, 1999).

The fertilization rate is extremely high in ewes after natural mating at a spontaneous oestrus, indicating a difference in cervical function between ewes inseminated naturally and ewes inseminated artificially. It is probable that the patency of the ovine cervix to semen is increased at the time of natural oestrus to facilitate sperm transport and fertilization. The low success rate of artificial insemination in sheep induced to ovulate by either withdrawal of progesterone pessaries or systemic prostaglandin administration indicates an inhibition of normal cervical function (Gordon, 1997). The present study investigated the inflammatory process in the ovine cervix and its possible inhibition when oestrus is synchronized by measuring IL-8 gene expression as a marker of inflammation throughout natural and induced oestrous cycles. The expression of IL-8 in both the inseminated and uninseminated cervix was 
investigated, as semen has been reported to stimulate IL-8 gene expression and leukocyte infiltration in the cervix in other species (Denison et al., 1999a).

\section{Materials and Methods}

\section{Animals}

All experiments were carried out during the natural breeding season. Cervical tissues were obtained from naturally cyclic ewes killed at an abattoir $(n=49)$. All other animals, including ewes treated with progesterone $(n=17)$ or prostaglandin $(n=18)$ at various times throughout the synchronized cycle, and progesterone-synchronized, artificially inseminated $(n=4)$ or uninseminated $(n=2)$ ewes at oestrus, were killed by intravenous lethal dose of sodium pentobarbitone (Euthatal; Rhône Mérieux Ltd, Harlow). Ewes were considered to be in oestrus if they stood and exhibited overt signs of 'heat' when challenged by a vasectomized ram. The stage of the oestrous cycle of all ewes was confirmed at slaughter by visual inspection of the ovaries and corpora lutea as described by Oldham and Lindsay (1980).

Progesterone-synchronized animals were treated by a standard method using intravaginal sponges containing $30 \mathrm{mg}$ fluorogestone acetate (Chronogest; Intervet, Cambridge) for 12 days. After the removal of the sponges, the ewes received an i.m. injection of 650 iu equine chorionic gonadotrophin (Intervet, Cambridge). Animals synchronized with prostaglandin received two i.m. injections, 9 days apart, of $6 \mathrm{mg}$ luprostinol (Proslovin; Intervet). Inseminated animals received $0.2 \mathrm{ml}$ fresh semen $36 \mathrm{~h}$ after sponge withdrawal and were killed $12 \mathrm{~h}$ later. All procedures complied with the Animals (Scientific Procedures) Act of 1986. Tissue was rapidly frozen in isopentane chilled over dry ice and stored at $-80^{\circ} \mathrm{C}$.

\section{Riboprobe synthesis}

The gene encoding IL-8 is highly conserved; human and ovine genes have $80 \%$ homology. The first 400 bp fragment of the human IL-8 gene (accession number M28130; a gift from Professor Matsushima, Department of Molecular Preventive Medicine, School of Medicine, The University of Tokyo) was directionally cloned into Bluescript M13 (-) vector. Plasmids were restricted, using Sac 1 or Sal 1 and the linearized DNA was isolated (Promega DNA Wizard Kit; Promega, Madison, WI) for preparation of ${ }^{35}$ S-labelled riboprobes for in situ hybridization. In brief, the probes were prepared in a solution containing $1 \mu \mathrm{g}$ template DNA, $1 \times$ transcription buffer, $10 \mathrm{mmol}$ dithiothreitol $\mathrm{I}^{-1}$ (DTT),

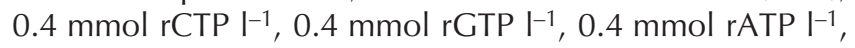
$0.04 \cup$ RNase inhibitor $\mu \mathrm{I}^{-1}, 8 \mu \mathrm{Ci}{ }^{\left.{ }^{35} \mathrm{~S}\right)}$ UTP $\mu \mathrm{I}^{-1}$ and transcribed with $0.8 \mathrm{U}$ T7 or T3 RNA polymerase $\mu \mathrm{I}^{-1}$ to generate antisense and sense riboprobes, respectively. This was incubated for $1.5 \mathrm{~h}$ at $37^{\circ} \mathrm{C}$ before digestion with $0.08 \cup$ RQ-1 DNase $\mu^{-1}$ for $30 \mathrm{~min}$ at $37^{\circ} \mathrm{C}$. Unincorporated probe was removed by centrifugation at $600 \mathrm{~g}$ for $5 \mathrm{~min}$ at room temperature through Chromospin columns
(Clontech, Basingstoke) and incorporation was checked on a liquid scintillation counter (Packard 1900TR). The final probe was diluted in hybridization solution, 50\% (v/v)

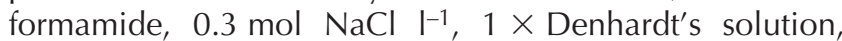
$10 \mathrm{mmol}^{\text {Tris }} \mathrm{I}^{-1}, 1 \mathrm{mmol}$ EDTA $\mathrm{I}^{-1}, 10 \mathrm{mmol}^{\mathrm{DTT}} \mathrm{I}^{-1}, 10 \%$

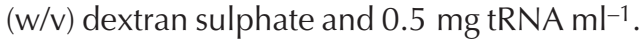

\section{In situ hybridization}

Cryostat transverse sections (20 $\mu \mathrm{m}$ in thickness) were cut from the mid-region of the cervix and thaw mounted on to gelatin- or poly-L-lysine-coated slides. Adjacent sections, for labelling with sense and antisense probes, were fixed in $4 \%(\mathrm{w} / \mathrm{v})$ paraformaldehyde in $0.1 \mathrm{~mol} \mathrm{PBS}^{-1}$ for $20 \mathrm{~min}$ at $4^{\circ} \mathrm{C}$, washed in PBS, incubated in $0.1 \mathrm{mmol}$ triethanolamine $\mathrm{I}^{-1}$ for $2 \mathrm{~min}$ and acetylated in $0.1 \mathrm{mmol}$ triethanolamine $\mathrm{I}^{-1}$ and $0.25 \%(\mathrm{v} / \mathrm{v})$ acetic anhydride for $10 \mathrm{~min}$. Sections were dehydrated through a graded series of ethanol and dried under vacuum before hybridization with riboprobes at $10^{6}$ c.p.m. $\mu \mathrm{l}^{-1}$ for $18 \mathrm{~h}$ at $58^{\circ} \mathrm{C}$. After hybridization, sections were desalted through a series of washes in standard saline citrate to a final stringency of $0.1 \times$ SSC at $60^{\circ} \mathrm{C}$ for $30 \mathrm{~min}$, treated with RNase A and dehydrated in ethanol. Air-dried slides were apposed to Hyperfilm $\beta$ max (Amersham International, Amersham) together with autoradiographic $\left({ }^{14} \mathrm{C}\right)$ micro-scale standards (Amersham International) for 4 weeks at room temperature for autoradiography.

\section{Quantification of in situ hybridization}

Autoradiographs of sections and the $\left({ }^{14} \mathrm{C}\right)$ microscale standards were scanned on a Umax Power Look II (UMAX Data Systems, Fremont, CA) using Adobe Photoshop (Adobe Systems Inc., San Francisco, CA). Integrated absorbances of the luminal epithelium and the fibroblastic cells were calculated using the Image Pro-plus system (Media Cybernetics, Silver Spring, MD) and the standard curve generated from the $\left({ }^{14} \mathrm{C}\right)$ microscales in which values are given as $\mathrm{nCi} \mathrm{g}^{-1}$. The values obtained from control serial sections incubated with a sense probe were designated background labelling and these values were subtracted from those obtained using the antisense probe; this procedure effectively eliminates the contribution of nonspecific binding. In situ hybridization experiments for each animal were repeated a minimum of three times, using sense and antisense probes on serial sections from each animal.

\section{Radioimmunoassays}

A 125 -labelled progesterone double-antibody radioimmunoassay was used to measure plasma progesterone concentrations in single blood samples taken from each of the naturally cyclic ewes at the time of harvesting (McNeilly and Fraser, 1987). The sensitivity limit of the assay was $0.51 \mathrm{ng} \mathrm{ml}^{-1}$ and the intra- and interassay coefficients of variation were 8.6 and $11 \%$, respectively. 


\section{Immunohistochemistry}

Cryostat cut tissue sections $(10 \mu \mathrm{m}$ in thickness) were fixed in $4 \%(\mathrm{w} / \mathrm{v})$ paraformaldehyde in $1 \times$ PBS on ice for $20 \mathrm{~min}$. Non-specific binding sites were blocked and the tissue was permeabilized with $1 \%$ normal goat serum (NGS) plus $0.1 \%(\mathrm{w} / \mathrm{v})$ saponin in $1 \times$ PBS. Sections were then incubated overnight at $4^{\circ} \mathrm{C}$ in a humid chamber with ovinespecific IL-8 polyclonal antibody (Chemicon, Harrow), diluted 1:750 in $1 \times$ PBS containing $0.1 \%$ NGS. Control sections were treated, simultaneously, by replacing the primary antibody with an equal concentration of rabbit IgG. Sections were then washed in $1 \times$ PBS containing $0.1 \%$ NGS before a $2 \mathrm{~h}$ incubation at room temperature with Fluorescein goat anti-rabbit antibody at 1:200 (Vector Laboratories, Peterborough). After a final wash in $1 \times$ PBS the sections were mounted in Vectastain (Vector Laboratories, Burlingame, CA).

\section{Statistical analysis}

Statistical analysis was carried out by first pooling values obtained from the in situ hybridization experiments to give a mean figure for each time point of the oestrous cycle. The number of in situ hybridization experiments is detailed for each group of animals in the figure legends. A linear model was used in which individual sheep and separate experiments were taken as random factors. The statistical significance between days of the oestrous cycle and treatment effects was tested by restricted maximum likelihood (REML), which was run using Genstat (5th Edn, Release 4.2). REML can be regarded as a generalization of analysis of variance (ANOVA) for unbalanced data (Robinson et al., 1982) and was used because of the variation in number of animals at each day of the oestrous cycle to be compared.

The skew in the observed data indicated that a log-transformation would be appropriate. The results of the initial analysis were corroborated by the log-transformation and thus presented on the original scale. Values were calculated as a percentage of those obtained at natural oestrus to ascertain the overall effects of insemination on IL-8 expression in the cervix and to allow a direct comparison to be made between IL-8 gene expression at natural oestrus, synchronized oestrus, and after insemination.

The linear relationship between IL-8 gene expression and progesterone concentrations was determined by calculating the correlation coefficient.

\section{Results}

\section{Natural oestrous cycle}

In situ hybridization revealed that IL-8 gene expression was discretely localized to the luminal epithelium and fibroblastic cells in the connective tissue stroma of the cervix in all samples studied (Fig. 1a,b). Immunostaining for IL-8 was restricted to the luminal epithelium of the cervix in agreement with IL-8 mRNA gene expression (Fig. 1c,d).
However, the gene expression of IL-8 varied considerably throughout the oestrous cycle in both the luminal epithelium and the fibroblastic cells (Fig. 2a,b). This observation was confirmed using semi-quantitative analysis of IL-8 gene expression, which revealed that, although expression was present throughout the oestrous cycle, it was significantly higher at oestrus (day 0 ) in both the luminal epithelium and fibroblastic cells, and at day 5 of the cycle (Fig. 2a,b) in the luminal epithelium $(P<0.05)$, when compared with the expression during the remainder of the cycle. IL-8 expression at oestrus was significantly higher $(P<0.001)$ than it was at the luteal phase (Fig. 3). IL-8 expression was inversely related to plasma progesterone concentrations (Figs 2a and 4): high IL-8 gene expression occurred when progesterone concentrations were low. This inverse relationship was confirmed by the calculation of the correlation coefficient of IL-8 concentrations against progesterone concentrations as -0.57 .

\section{Progesterone-synchronized oestrous cycle}

No apparent pattern was found in IL-8 gene expression during the induced oestrous cycle in the luminal epithelium in animals treated with progesterone, although expression was significantly increased at about days 5-6 of the cycle $(P<0.001$; Fig. 5a). IL-8 expression at induced oestrus was significantly lower than that at natural oestrus $(P<0.001$; Fig. 3). During the luteal phase of the oestrous cycle no differences in IL-8 expression were found among naturally oestrous ewes and ewes treated with progesterone or with prostaglandin (Fig. 3).

\section{Prostaglandin-synchronized oestrous cycle}

There was no significant difference in IL-8 gene expression throughout the oestrous cycle after administration of prostaglandin (Fig. 5b). However, IL-8 gene expression at oestrus was again significantly lower when compared with expression at natural oestrus $(P<0.05)$, but was not significantly different at oestrus from the animals treated with progesterone (Fig. 3).

\section{Progesterone-synchronized oestrous cycle and insemination}

IL-8 gene expression measured at oestrus in uninseminated, progesterone-synchronized ewes confirmed the findings in the artificial synchronization experiment in that expression was significantly lower $(P<0.05)$ than at natural oestrus (Figs 3 and 6). IL-8 expression in the luminal epithelium of the cervix in ewes after insemination following progesterone synchronization of the cycle was significantly higher $(P<0.05)$ than it was in uninseminated, progesteronesynchronized ewes (Fig. 6). Comparison of IL-8 gene expression after insemination with that seen at natural oestrus demonstrates that insemination increases IL-8 gene expression in progesterone-synchronized animals almost to the expression seen at a natural oestrus. 

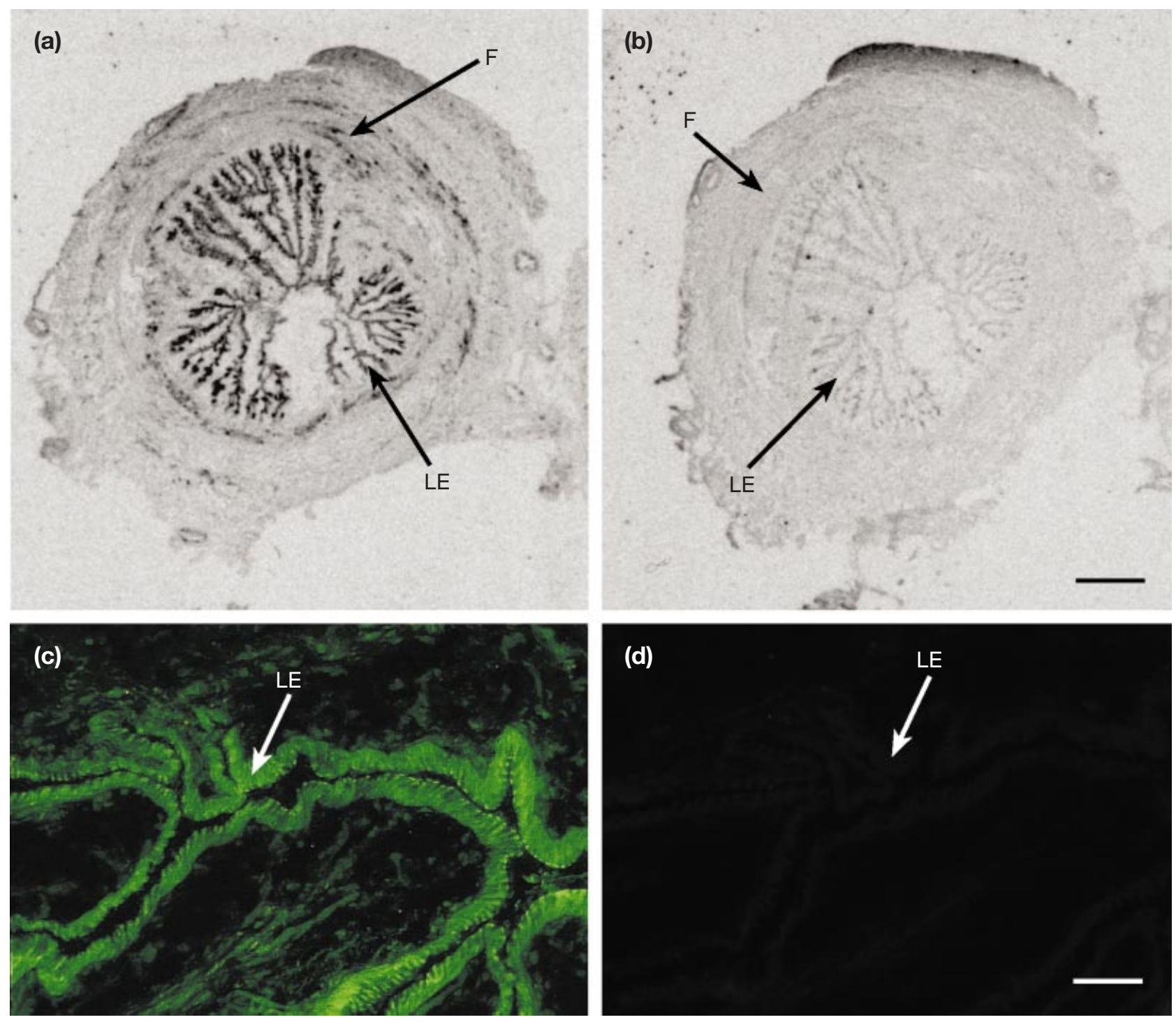

Fig. 1. Autoradiographs of transverse cryostat serial sections of the whole ovine cervix at oestrus hybridized with either (a) the ${ }^{35} \mathrm{~S}$ antisense riboprobe or (b) the ${ }^{35} \mathrm{~S}$ sense riboprobe. Specific binding revealing interleukin 8 (IL-8) gene expression can be seen over the luminal epithelium (LE) and fibroblastic cells in the connective tissue stroma (F). Immunolocalization of IL-8 in the cervix using (c) an ovine specific antibody and (d) control section incubated with rabbit IgG control. Distinct immunofluorescent staining in the LE confirms that IL-8 gene expression reflects the presence of IL-8 protein. Scale bars represent (a,b) $0.25 \mathrm{~cm}$ and (c,d) $100 \mu \mathrm{m}$.

\section{Discussion}

In sheep, cervical artificial insemination at a hormonesynchronized oestrus results in lower conception rates compared with those in naturally oestrous ewes (Gordon, 1997), indicating that the function of the cervix is compromised by hormone synchronization. The anatomy of the cervix in sheep is complex and comprises a tightly interlocking structure of about $6 \mathrm{~cm}$ in length. Cervical function at parturition involves an inflammatory cascade resulting in degradation of collagen, the main component of the cervix, and cervical dilation (Kelly, 1996), but little is known about the function of the ovine cervix during natural or artificial insemination. A host of chemical messengers mediate the complex physical changes that take place during inflammation, and IL-8 plays an essential role late in the cascade as the major signal for the infiltration of neutrophils into a tissue (Baggiolini, 1998). Neutrophils contain high concentrations of collagenase and elastase, enzymes that are important in cervical softening.

The results of the present study demonstrate high IL-8 gene expression at oestrus and strongly indicate that a degree of inflammation, and hence cervical dilation, occurs at this time, presumably to facilitate transcervical transport of spermatozoa. Administration of human IL-8 to ewes at this time generally enhances cervical dilation and the 
(a)

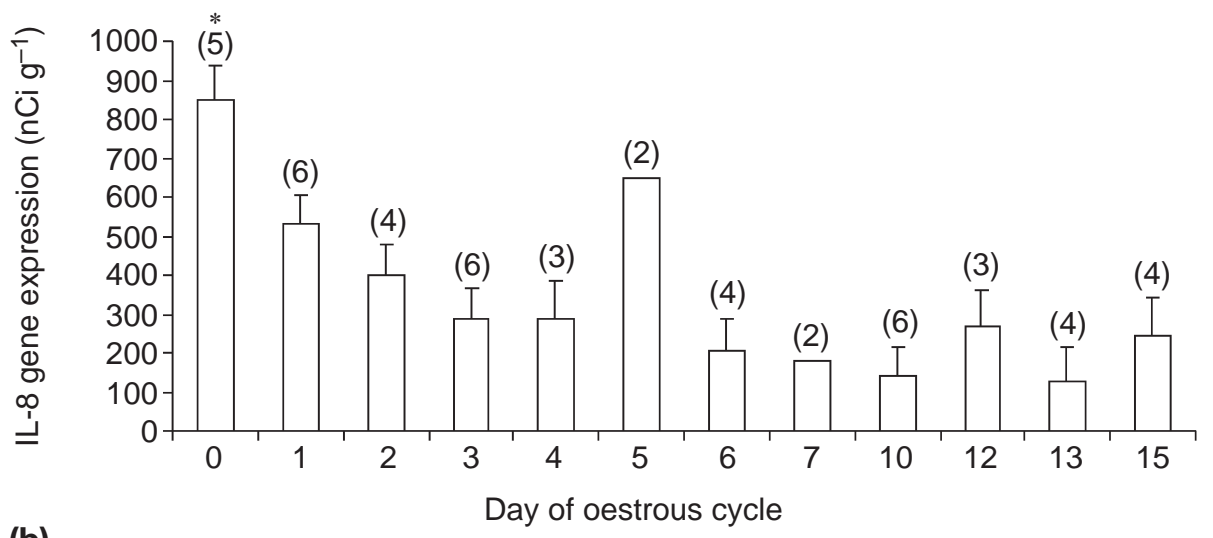

(b)

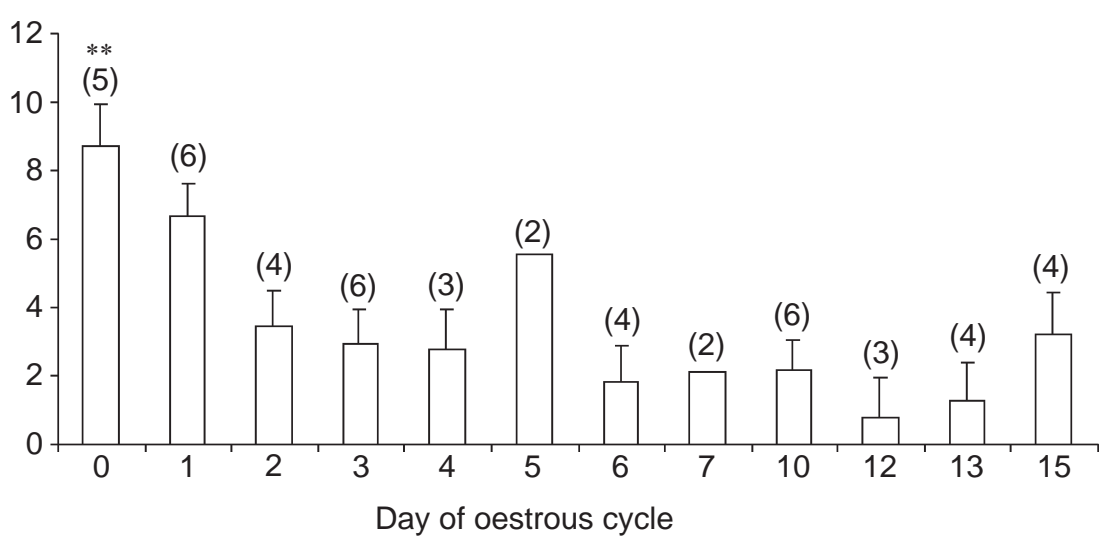

Fig. 2. Interleukin 8 (IL-8) gene expression derived from integrated absorbance in (a) the luminal epithelium and (b) the fibroblastic cells of the ovine cervix during the natural oestrous cycle. The luminal epithelium shows IL-8 gene expression several orders of magnitude higher than that seen in the fibroblastic cells. IL-8 gene expression is highest at about the time of oestrus in both types of cell. In the luminal epithelium IL-8 gene expression was also high at day 5 of the oestrous cycle. IL-8 gene expression at oestrus and at day 5 was found to be significantly higher $\left({ }^{*} P<0.05\right)$ than at the other days of the cycle in the luminal epithelium, but was only significantly higher $\left({ }^{* *} P<0.001\right)$ at oestrus in the fibroblastic cells. Numbers of animals are shown in brackets. The values for the individual animals were calculated using pooled results from between four and six separate experiments in situ.

degree of penetration (Croy et al., 1999). The higher IL-8 expression found at oestrus correlates strongly with the high oestradiol and low progesterone concentrations found at this stage of the cycle (Hauger et al., 1977). IL-8 expression is also high at day 5 of the oestrous cycle. These data are derived from samples of two animals and therefore may not be truly representative. However, high IL-8 gene expression at this time may be the result of a second wave of folliculogenesis and an increase in oestradiol concentrations seen in sequential samples from individual animals (Hauger et al., 1977). The contention that the increase in IL-8 gene expression observed at day 5 is due to an increase in oestradiol is tentative and a full investigation into the relationship between oestradiol and IL-8 should be undertaken.

Progestogen pessaries are used widely for synchronization of oestrus (Gordon, 1997), and the present study shows that this treatment inhibits the increase in IL-8 gene expression that occurs in the ovine cervix at spontaneous oestrus. The expression of IL-8 during the luteal phase of the

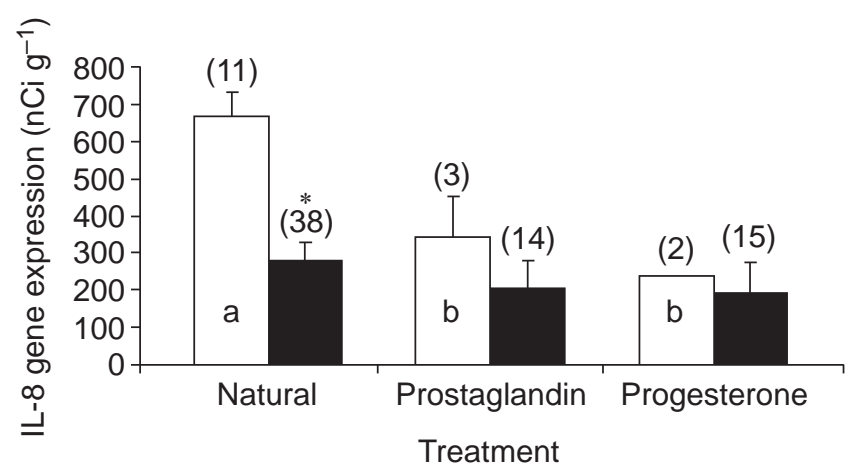

Fig. 3. Interleukin 8 (IL-8) gene expression derived from integrated absorbance in the luminal epithelium of the cervix of naturally cyclic and progesterone- and prostaglandin-synchronized ewes. Data have been grouped into the oestrous $(\square)$ and luteal $(\square)$ phases to illustrate the differences between the two stages of the oestrous cycle within each treatment. Numbers of animals are shown in brackets. IL-8 gene expression at natural oestrus, marked ' $a$ ', is significantly different from values marked ' $b$ '. *Significantly different from value at oestrus $(P<0.001)$. 


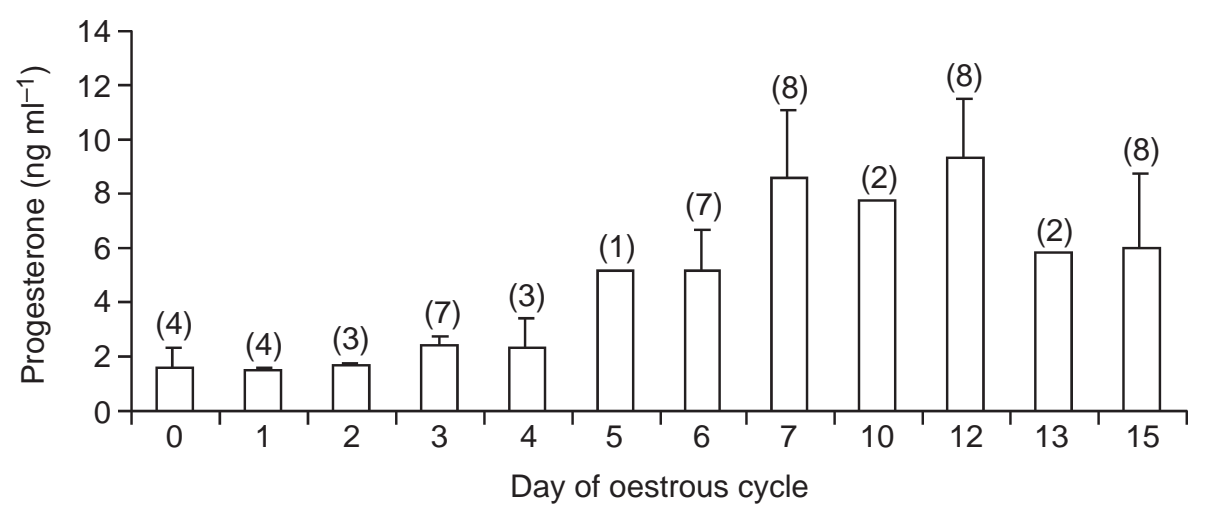

Fig. 4. Progesterone concentrations in the blood plasma of individual ewes. There appears to be an inverse relationship between progesterone concentration and interleukin 8 (IL-8) gene expression (see Fig. 2a), confirmed by a correlation coefficient of -0.57 . Numbers of animals are shown in brackets.

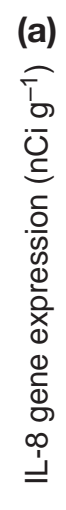

(b)

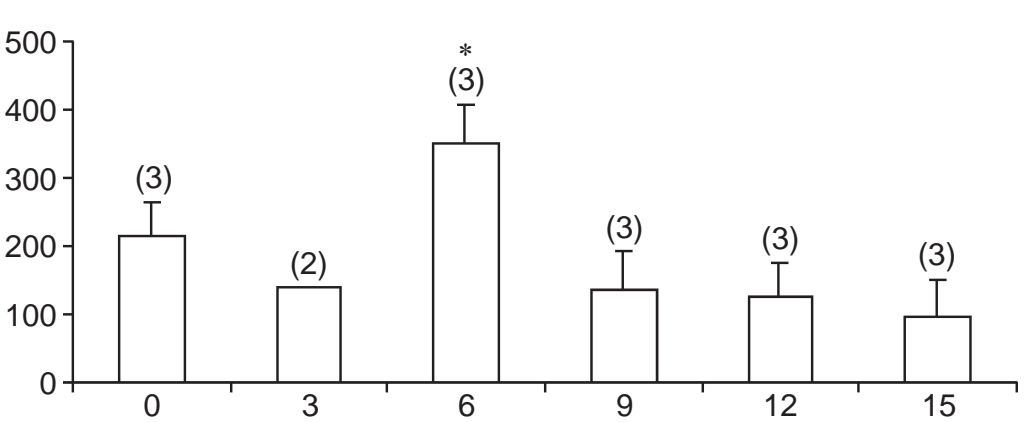

Day of oestrous cycle

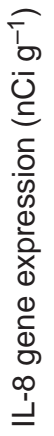

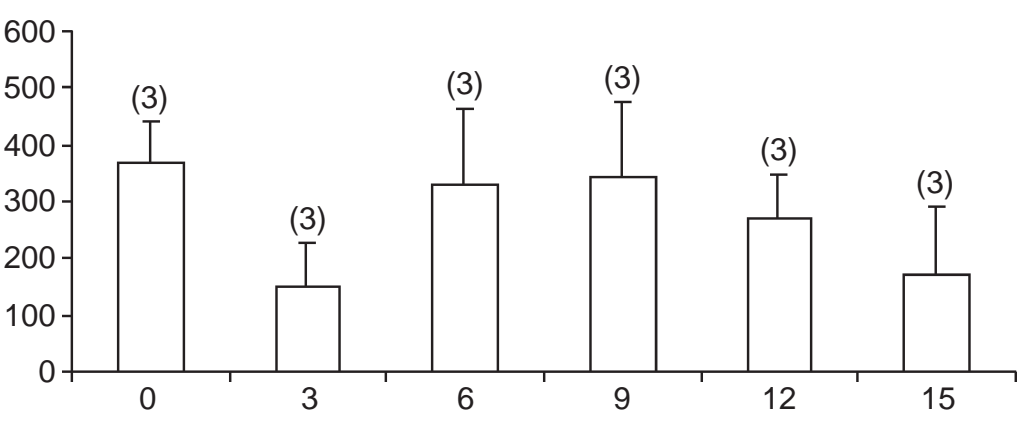

Day of oestrous cycle

Fig. 5. Comparative interleukin 8 (IL-8) gene expression derived from integrated absorbance in the luminal epithelium of the cervix of (a) progesterone-synchronized ewes and (b) prostaglandin-synchronized ewes throughout the oestrous cycle. Numbers of animals are shown in brackets and values for each individual animal are based on three separate in situ hybridization experiments. *Significantly different from all other values $(P<0.001)$.

induced cycle is not significantly different from the natural cycle. Thus, the increase in IL-8 at oestrus is specifically inhibited by progesterone synchronization of oestrus. This is not a surprising result as progesterone has a strong inhibitory effect on inflammation, and specifically on the expression of IL-8 in the cervix and other female reproductive tissues
(Ito et al., 1994; Kelly et al., 1994; Critchley et al., 1996, 1999; Elliott et al., 1998).

A separate experiment to test the effect of semen on IL-8 expression confirmed the effect of progesterone synchronization of oestrus on the increase in IL-8 expression. Ewes in which oestrus had been artificially synchronized were 


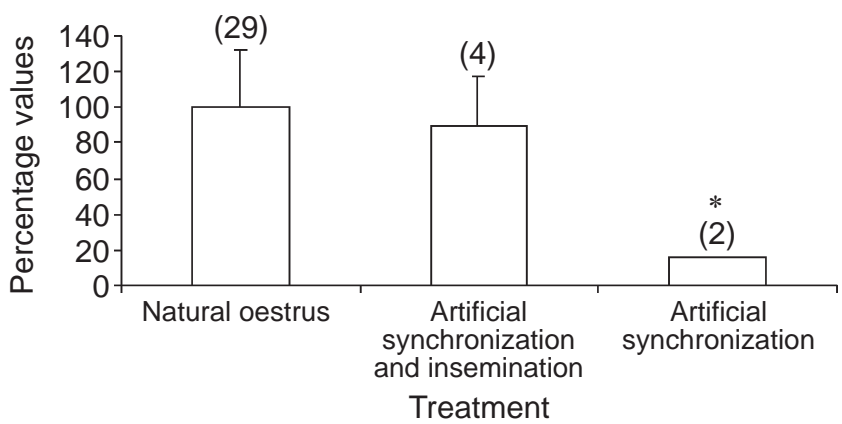

Fig. 6. Interleukin 8 (IL-8) gene expression in the luminal epithelium of the ovine cervix at oestrus expressed as a percentage of the values obtained at natural oestrus. Results of three separate experiments are compared: natural oestrus, artificial synchronization and artificial synchronization followed by insemination. Synchronization was carried out using a progesterone treatment. *Significantly different from all other values $(P<0.05)$.

divided into two groups, either inseminated or uninseminated, and IL-8 expression in the luminal epithelium was measured in each group. IL-8 expression was higher in the luminal epithelium of the cervix after insemination, and similar to that found at natural oestrus in unmated control ewes. The effect of insemination on IL-8 expression at natural oestrus was not measured in the present study, but extrapolation of the present findings indicates that the already comparatively high IL-8 expression seen at natural oestrus will be increased even further after insemination or natural mating, resulting in relatively high IL-8 gene expression. Thus, semen amplifies the inflammation seen at natural oestrus by increasing IL-8 gene expression. This finding confirms observations in rabbits that the number of leucocytes in the cervix is increased after insemination (Tyler, 1977) and more recently that explants of human cervix incubated in the presence of seminal plasma show increased release of IL-8 (Denison et al., 1999a).

The administration of prostaglandin $\left(\mathrm{PGF}_{2 \alpha}\right)$ to synchronize oestrus was also found to inhibit the increase in IL-8 gene expression. This result was surprising, as prostaglandins are a major part of the inflammatory cascade and are important in cervical ripening (Gross et al., 1998; Reese et al., 2000), and prostaglandin $E_{2}$ stimulates IL-8 release from cervical explants in culture (Denison et al., 1999b). However, prostaglandins have both pro-inflammatory and anti-inflammatory actions, depending on their site of action and their interaction with cytokines (Kelly, 1996). The mechanisms by which prostaglandin inhibits IL-8 expression in the present study are unknown, although they may be related to the associated marked decrease in progesterone (Acritopoulou et al., 1977) compared with the gradual decline that accompanies natural luteolysis (Haresign, 1985).

In conclusion, IL-8 was shown to be differentially expressed in the ovine cervix during the oestrous cycle, and maximum expression occurred at about the time of oestrus, indicating that the components of the inflammatory cascade are present and vary during the natural oestrous cycle, and that the highest activity occurs at oestrus. In addition, IL-8 gene expression is significantly inhibited by the synchronization of oestrus by either progesterone or prostaglandin, and insemination can increase IL-8 expression in progesterone-synchronized ewes to values that are close to those seen at oestrus in non-mated ewes. In ewes at natural oestrus, insemination will result in very high IL-8 gene expression and a marked inflammation of the cervix, presumably to facilitate the passage of semen to the uterus. This mechanism may explain the low rates of fertilization obtained after cervical artificial insemination, which is invariably carried out on synchronized ewes. By bypassing the cervix and using intrauterine insemination, fertility is increased, emphasizing the compromised cervical function which, on the basis of the results of the present study, involves reduced IL-8 receptor expression.

The authors would like to thank Claus Mayer, Biomathematics and Statistics Scotland (BIOSS), for his help with the statistical analysis of the data in this paper. This study was supported by the Scottish Executive Environment and Rural Affairs Department and the Meat and Livestock Commission.

\section{References}

Acritopoulou S, Haresign W, Foster JP and Lamming GE (1977) Plasma progesterone and LH concentrations in ewes after injection of an analogue of prostaglandin F-2alpha Journal of Reproduction and Fertility 49 337-340

Arici A, Oral E, Bukulmez O, Buradagunta S, Engin O and Olive DL (1996) Interleukin-8 expression and modulation in human preovulatory follicles and ovarian cells Endocrinology 137 3762-3769

Baggiolini M (1998) Chemokines and leukocyte traffic Nature 392 565-568

Banner M (1995) Report on Secretary of State's Working Party on the Ethical Implications of Advanced Breeding Techniques for Farm Animals HMSO, London

Barclay CG, Brennand JE, Kelly RW and Calder AA (1993) Interleukin-8 production by the human cervix American Journal of Obstetrics and Gynaecology 169 625-632

Critchley HO, Kelly RW, Lea RG, Drudy TA, Jones RL and Baird DT (1996) Sex steroid regulation of leukocyte traffic in human decidua Human Reproduction $112257-2262$

Critchley HO, Jones RL, Lea RG, Drudy TA, Kelly RW, Williams AR and Baird DT (1999) Role of inflammatory mediators in human endometrium during progesterone withdrawal and early pregnancy Journal of Clinical Endocrinology and Metabolism 84 240-248

Croy BA, Prudencio J, Minhas K, Ashkar AA, Galligan C, Foster RA, Buckrell B and Coomber BL (1999) A preliminary study on the usefulness of hulL-8 in cervical relaxation of the ewe for artificial insemination and for embryo transfer Theriogenology 52 271-287

Denison FC, Grant VE, Calder AA and Kelly RW (1999a) Seminal plasma components stimulate interleukin-8 and interleukin-10 release Molecular Human Reproduction 5 220-226

Denison FC, Calder AA and Kelly RW (1999b) The action of prostaglandin E2 on the human cervix: stimulation of interleukin 8 and inhibition of secretory leukocyte protease inhibitor American Journal of Obstetrics and Gynecology 180 614-620

Dobson H (1988) Softening and dilation of the uterine cervix Oxford Review of Reproductive Biology 10 491-514

Ekerhovd E, Brannstrom M, Weijdegard B and Norstrom A (2000) Nitric oxide synthases in the human cervix at term pregnancy and effects of nitric oxide on cervical smooth muscle contractility American Journal of Obstetrics and Gynecology 183 610-616 
Elliott CL, Kelly RW, Critchley HO, Riley SC and Calder AA (1998) Regulation of interleukin 8 production in the term human placenta during labor and by antigestagens American Journal of Obstetrics and Gynecology $179215-220$

Garcia-Velasco JA and Arici A (1999) Chemokines and human reproduction Fertility and Sterility 71 983-993

Gordon I (1997) Controlled Reproduction in Sheep and Goats pp 86-115. CAB International, Wallingford

Gross GA, Imamura T, Luedke C, Vogt SK, Olson LM, Nelson DM, Sadovsky Y and Muglia LJ (1998) Opposing actions of prostaglandins and oxytocin determine the onset of murine labor Proceedings National Academy of Sciences USA $9511875-11879$

Haresign W (1985) Comparison of the rate of decline in plasma progesterone concentrations at a natural and progesterone-synchronized oestrus and its effect on tonic LH secretion in the ewe Journal of Reproduction and Fertility 75 231-236

Hauger RL, Karsch FJ and Foster DL (1977) A new concept for control of the estrous cycle of the ewe based on the temporal relationships between luteinizing hormone, estradiol and progesterone in peripheral serum and evidence that progesterone inhibits tonic LH secretion Endocrinology $101807-817$

Hawk HW and Cooper BS (1977) Sperm transport into the cervix of the ewe after regulation of estrus with prostaglandin or progestogen Journal of Animal Science 44 638-644

Ito A, Imada K, Sato T, Kubo T, Matsushima K and Mori Y (1994) Suppression of interleukin 8 production by progesterone in rabbit uterine cervix Biochemical Journal 301 183-186

Kelly RW (1996) Inflammatory mediators and parturition Reviews of Reproduction 1 89-96

Kelly RW, Illingworth P, Baldie G, Leask R, Brouwer S and Calder AA (1994) Progesterone control of interleukin-8 production in endometrium and chorio-decidual cells underlines the role of the neutrophil in menstruation and parturition Human Reproduction 9 253-258

Ledingham MA, Thomson AJ, Young A, Macara LM, Greer IA and Norman
JE (2000) Changes in the expression of nitric oxide synthase in the human uterine cervix during pregnancy and parturition Molecular Human Reproduction 6 1041-1048

McKelvey W, Robinson JJ, Aitken RP and Henderson G (1985) The evaluation of a laparoscopic insemination technique in ewes Theriogenology 24 519-535

McNeilly AS and Fraser HM (1987) Effect of gonadotrophin-releasing hormone agonist-induced suppression of $\mathrm{LH}$ and FSH on follicle growth and corpus luteum function in the ewe Journal of Endocrinology 115 273-282

Oldham CM and Lindsay DR (1980) Laparoscopy in the ewe: a photographic record of the ovarian activity of ewes experiencing normal or abnormal estrous cycles Animal Reproduction Science 3 119-124

Reese J, Paria BC, Brown N, Zhao X, Morrow JD and Dey SK (2000) Coordinated regulation of fetal and maternal prostaglandins directs successful birth and postnatal adaptation in the mouse Proceedings National Academy of Sciences USA 97 9759-9764

Robinson DL, Thopson R and Digby PGN (1982) REML - a program for the analysis of non-orthogonal data by restricted maximum likelihood Compstat 1982 Proceedings in Computational Statistics Part II (Supplement) 231-232

Tyler KR (1977) Histological changes in the cervix of the rabbit after coitus Journal of Reproduction and Fertility 49 341-345

Wu WX, Ma XH, Smith GC, Mecenas CA, Koenen SV and Nathanielsz PW (2000) Prostaglandin dehydrogenase mRNA in baboon intrauterine tissues in late gestation and spontaneous labor American Journal of Physiology - Regulatory Integrative and Comparative Physiology 279 R1082-R1090

Received 18 January 2002.

First decision 7 March 2002.

Revised manuscript received 30 May 2002.

Accepted 13 June 2002. 